\title{
PERAN GURU DALAM MENGEMBANGKAN SIKAP SOSIAL SISWA PADA MATA PELAJARANIPS DI KELAS VII MTS NURUL FATAH TENGGIR
}

\author{
Fairus Sadek ${ }^{1,}$ Dassucik ${ }^{2,}$ Ahmad Hafas Rasyidi ${ }^{3}$, Irma Noervadilah ${ }^{4}$ \\ ${ }^{1}$ Mahasiswa Prodi Pendidikan Ekonomi STKIP PGRI Situbondo \\ 2,3,4 Dosen Pendidikan Ekonomi STKIP PGRI Situbondo \\ email: andiyflestiyo86@gmail.com
}

Received: Nov 5, 2020 Revised: Nov 9, 2020 Accepted: Nov 15, 2020

\begin{abstract}
ABSTRAK
Salah satu penilaian hasil belajar siswa yaitu penilaian sikap. Hal ini sesuai dengan Peraturan Menteri Pendidikan dan Kebudayaan Republik Indonesia Nomor 23 Tahun 2016 Tentang Standar Penilaian Pendidikan yang menyebutkan bahwa penilaian sikap merupakan kegiatan yang dilakukan oleh pendidik untuk memperoleh informasi deskriptif mengenai perilaku peserta didik. Berbagai masalah terjadi akibat kurang berkembangnnya sikap sosial yang baik di kehidupan terutama di sekolah. Seperti kasus beredarnya video kekerasan sejumlah siswa yang terjadi di sekolah. Kasus kekerasan tersebut menggambarkan sikap tanggung jawab siswa yang tidak baik. Sebagai seorang siswa di sekolah seharusnya dapat menjalankan tanggung jawab sebagaimana mestinya. Guru sebagai sosok yang menjadi teladan merupakan salah satu faktor yang mempengaruhi dalam mengembangkan sikap sosial siswa. Siswa sosial yang dikembangkan disekolah, jujur, disiplin, tanggung jawab,santun, percaya diri, dan peduli. Peran guru dalam mengembangkan sikap sosial siswa disekoalh sangat berarti sekali bagi kepribadian siswa, peran guru sebagai demonstrator, komunikator, oganisator, motivator, inspirator, evaluator dan pendidik. Perbedaannya terletak pada peran guru sebagai komunikator, motivator, inspirator, dan pendidik.
\end{abstract}

Kata Kunci : Peran Guru, Mengembangkan Sikap Sosial

\section{PENDAHULUAN}

Pendidikan sebagai usaha sadar yang diberikan seseorang guna membentuk kepribadian dan pendewasaan diri merupakan bagian terpenting dalam kehidupan yang tidak bisa dipisahkan (Depdiknas, 2012:15). Pendidikan sebagai usaha sadar yang diberikan seseorang guna membentuk kepribadian dan pendewasaan diri merupakan bagian terpenting dalam kehidupan yang tidak bisa dipisahkan. Oleh karena itu dengan adanya pendidikan maka diperlukan faktor-faktor sebagai penunjang pendidikan, salah 
satunya adalah menerapkan sikap kedisiplinan. Adanya kedisiplinan itu diharapkan dapat menyiapkan manusia untuk dapat memegang peranan tertentu dalam masyarakat di masa mendatang.

Pada jalur pendidikan formal terdapat kurikulum yang digunakan sebagai pedoman pendidikan. Indonesia telah mengalami perubahan kurikulum, mulai dari kurilukum 1947, 1964, 1968, 1973, 1975, 1984, 1994, 1997, 2004, 2006, hingga 2013. Sejak Tahun 2013 pemerintah telah mengeluarkan kebijakan tentang penerapan kurikulum baru kemudian dikenal dengan kurikulum 2013. Kurikulum 2013 lahir dengan semangat untuk merekonstruksi pendidikan Indonesia agar mampu menjadi wadah bagi anak-anak Indonesia untuk mengembangkan segala potensi mereka (Wahyu Widodo, $2016: 2$ ).

Berdasarkan hasil observasi ditemukan bahwa guru-guru di MTs Nurul Fatah Tenggir Situbondo dapat mencontohkan dengan baik bagaimana seharusnya sikap sosial yang dimiliki siswanya, dan siswanya pun dapat mengaplikasikan sikap sosial dengan baik. Dari permasalahan di atas perlu dilakukan penelitian untuk membuktikan peran guru yang bagaimanakah yang dapat mengembangkan sikap sosial siswa di kelas VII di MTs Nurul Fatah Tenggir Situbondo. Sehubungan dengan hal tersebut MTs Nurul Fatah Tenggir merupakan salah satu madrasah yang ada dilingkungan pondok pesantren. MTs Nurul Fatah Tenggir dikenal sebagai madrasah dengan segudang prestasi, baik prestasi akademik maupun non akademik. Ada sejumlah kualifikasi yang dijamin akan dimiliki siswa-siswa lulusan MTs Nurul Fatah Tenggir, yaitu: (1) Memiliki akidah yang kuat. (2) Istiqomah dalam beribadah. (3) Tartil membaca al-Quran. (4) Hafal Juz amma, beberapa Al-quran dan Hadits. (5) Berbakti Kepada orang tua dan hormat pada guru. (6) Sayang dengan teman dan sesama. (7) Disiplin, (8) Peduli, (9) Percaya diri, (10) Senang membaca, (11) Memiliki life skill.

\section{METODE PENELITIAN}

Penelitian ini merupakan penelitian jenis penelitian kualitatif. Dalam penelitian kuantitatif, masalah yang dibawa oleh peneliti sudah jelas (Sugiyono, 2016:30). Pemeriksaan keabsahan data penelitian kualitatif dilakukan dengan teknik-teknik berikut: 


\section{Uji Kredibilitas}

Uji kredibilitas data atau kepercayaan terhadap data hasil penelitian kualitatif antara lain dilakukan dengan perpanjang pengamatan peningkatan ketekunan dalam penelitian, triangulasi, diskusi dengan teman sejawat, analisis kasus negatif, dan membercheck (Sugiono, 2011: 270).

Ada tiga macam triangulasi yaitu triangulasi sumber, triangulasi teknik atau metode, dan triangulasi waktu.

\section{Pengujian Transferability}

Supaya orang lain dapat memahami hasil penelitian kualitatif sehingga ada kemungkinan untuk menerapkan hasil penelitian tersebut, maka peneliti dalam membuat laporannya harus memberikan uraian yang rinci, jelas, sistematis, dan dapat dipercaya. (Sugiono, $2011: 277$ ).

\section{Pengujian Dependability}

Dalam penelitian kualitatif uji dependability dilakukan dengan melakukan audit terhadap keseluruhan proses penelitian. Jika peneliti tidak mempunyai dan tak dapat menunjukkan "jejak aktivitas lapangannya", maka depenabilitas penelitiannya patut diragukan (Sugiono, $2011: 277$ ).

\section{Pengujian Konfirmability}

Peneliti akan membandingkan data hasil pengamatan dengan hasil wawancara, kemudian membandingkan hasil wawancara dengan isi suatu dokumen yang berkaitan. Sebagai proses dalam menguji keabsahan data, peneliti memberikan kesempatan kepada responden untuk mengungkap pendapat dan jawaban secara mendalam terkait peran guru dalam mengembangkan sikap sosial siswa. Proses wawancara yang dilakukan secara santai agar responden tidak merasa canggung dan sulit dalam memberi jawaban.

\section{HASIL DAN PEMBAHASAN}

1. Sikap Sosial Yang Dikembangkan di Kelas VII Mata Pelajaran IPS di MTs

\section{Nurul Fatah Tenggir}

\section{a. Jujur}

Waktu pelaksanaan ulangan harian siswa mengerjakan soal ulangan harian dengan kemampuan sendiri, tidak melihat ke kanan atau kiri temannya. Siswa yang meminjam barang, baik milik temannya dan milik kelas atau sekolah, ketika pembelajaran di dalam kelas dapat dikembalikan dengan baik. Apabila ditemukan 
barang yang bukan milik pribadi siswa, siswa tidak mengambilnya dan memberitahu guru kemudian memberikan barang tersebut kepada guru.

\section{b. Disiplin}

Setiap hari siswa memakai seragam sekolah yang berbeda. Terlihat masih ada siswa yang belum memakai atribut seragam yang lengkap dan kurang rapi. Seperti pada hari Rabu dengan seragam pramuka beberapa siswa tidak memakai atribut, tidak membawa perlengkapan belajar buku pelajaran, sebenarnya siswa tersebut membawanya namun tidak dipakai ketika pelajaran IPS. Berdasarkan RPP yang telah dibuat oleh guru, pada setiap kegiatan pembukaan pembelajaran guru selalu mengingatkan siswa untuk mengutamakan sikap disiplin.

\section{c. Tanggung Jawab}

Sikap tanggung jawab juga dikembangkan melalui pelaksanaan piket kebersihan. Peneliti melihat terdapat jadwal piket siswa di depan kelas. Piket dapat dilaksanakan siswa dari awal masuk kelas hingga selesai pembelajaran. Hal ini juga terlihat pada pelajaran keterampilan membuat prakarya, sisa-sisa barang yang tidak digunakan (sampah) dibuang oleh siswa ke tempat sampah.

Pada saat istirahat jika terlihat tempat sampah kecil yang berada di dalam kelas sudah penuh, siswa membuangnya ke tempat sampah yang lebih besar berada di luar kelas. setiap pulang sekolah siswa merapikan kursi dan meja secara bersama-sama. Piket kebersihan kelas juga dilaksanakan siswa bersama-sama setiap hari Sabtu dengan membersihkan dan merapikan fasilitas di kelas sebelum kegiatan pembelajaran dimulai.

\section{d. Santun}

Siswa dapat mendengarkan dan menyimak guru atau teman yang sedang berbicara di depan kelas, kemudian menanggapi. Terdapat beberapa kali guru menegur siswa yang kurang memperhatikan guru atau teman yang sedang berbicara di depan kemudian siswa tersebut diam dan tidak membantah guru. Mayoritas siswa dapat berbicara dengan baik terhadap guru dan teman. Namun ada beberapa siswa yang berbicara kurang baik kepada teman dengan alasan karena temannya yang susah diatur. Pada dasarnya mereka tahu bagaimana cara bersikap sopan terhadap orang lain.

\section{e. Peduli}

Pelaksanaan pembelajaran di kelas dalam meminjamkan atau memberikan alat kepada temannya tanpa paksaan. Siswa mau meminjamkan alat kepada teman yang 
tidak membawa/memiliki apabila teman tersebut bilang dan barang tersebut bisa digunakan bersama-sama, alasan lain agar temannya bisa belajar atau menulis Selain itu, terlihat di lapangan ketika ada siswa yang kesulitan dalam belajar siswa yang lain membantunya. Siswa mau membantu temannya yang kesulitan memahami pelajaran agar temannya lebih paham, ada siswa yang mau membantu temannya jika temannya mau dibantu, ada juga siswa yang memilih untuk berdiam dan membiarkan temannya yang belum paham pelajaran bertanya pada guru.

\section{f. Percaya Diri}

Sikap percaya diri juga merupakan sikap yang dikembangkan disekolah. Percaya diri dikembangkan ketika pembelajaan yaitu siswa yang berani tampil di depan kelas untuk menjelaskan dan mengemukakan pendapat. Ada siswa yang memiliki alasan agar mendapat nilai, agar lebih berani dan percaya diri, ada yang beralasan supaya temannya tahu jawaban dia.

Banyaknya siswa berlomba-lomba mengacungkan tangan terlebih dahulu untuk dapat menjawab dan mengemukakan pendapatnya dari pertanyaan guru. Sikap toleransi dalam hal belajar maupun pergaulan juga merupakan sikap sosial yang dikembangkan di sekolah. Sikap toleransi yang dikembangkan yaitu siswa tidak memilih-milih mana teman yang miskin atau yang kaya, mana teman yang pintar atau yang tidak pintar. Mereka diajarkan untuk tidak melihat ras-ras atau golongan tertentu.

\section{Peran Guru Dalam Mengembangkan Sikap Sosial Siswa Pada Pelajaran IPS}

Berikut akan diulas mengenai peran guru dalam mengembangkan sikap sosial siswa.

\section{a. Sebagai Demonstrator}

Sikap terpuji yang nampak pada guru yaitu guru memulai dan mengakhiri pembelajaran tepat waktu, guru berpakaian rapi, sopan dan islami, guru berbicara dengan bahasa yang baik, tidak kasar. Guru membiasakan menjawab salam ketika siswa mengucapkan salam. Guru membimbing siswa untuk selalu berdo'a sebelum dan sesudah melakukan pekerjaan.

Guru menunjukkan cara agar setiap materi pelajaran dapat dipahami dan dihayati oleh setiap siswa dengan mengaitkan keadaan yang ada dilingkungan sekitar atau hal-hal yang ditemukan dalam kehidupan sehari-hari. Materi yang belum dipahami siswa, dijelaskan kembali dengan baik oleh guru. Guru memilih materi yang benar- 
benar dibutuhkan oleh peserta didik karena dalam pembelajaran materi pelajaran harus disesuaikan dengan kondisi peserta didik.

\section{b. Sebagai Pengelola Kelas}

Dalam kegiatan pembelajaran dipimpin oleh guru sesuai dengan tujuan pembelajaran yang akan dicapai dan waktu pembelajaran sesuai dengan jadwal yang telah ditentukan serta seluruh siswa dapat dikondisikan dengan baik. Guru mengatur tempat duduk secara berkelompok, terdapat 5 kelompok belajar dan penempatan duduk siswa secara heterogen dan digilir setiap seminggu sekali. Pengaturan tata letak duduk siswa kurang maksimal dikarenakan keterbatasan tempat, guru tidak bisa memindahkan meja dan kursi melainkan memindahkan tempat duduk siswa. Kegiatan memelihara lingkungan fisik kelas dilakukan dengan melihat situasi dan kondisi kelas, serta waktu yang guru luangkan untuk siswa bekerja bakti membersihkan kelas.

\section{c. Sebagai Mediator}

Pada saat pembelajaran berlangsung guru menggunakan media pembelajaran hanya pada keadaan tertentu. Media pembelajaran digunakan ketika siswa belum memahami materi pembelajaran yang disampaikan guru secara verbal. Guru melibatkan siswa untuk menggunakan media yang disediakan agar siswa tertarik dalam belajar. Selain itu, media pembelajaran disediakan oleh guru.

\section{d. Sebagai Fasilitator}

Sebagai fasilitator, Guru menyediakan seluruh perangkat pembelajaran sebelum pembelajaran dimulai (seperti silabus, kurikulum, RPP, bahan evaluasi, dan penilaian). Guru menyediakan seluruh perangkat pembelajaran seperti silabus, RPP dan penilaian diawal semester dan diarsipkan dalam 1 bundel berdasarkan mata pelajaran. Dalam melaksanaan kegiatan pembelajaran yang dilakukan di kelas guru sudah terlihat sangat siap. Karena sudah terjadwal apa yang akan dilaksanakan dan apa yang akan diajarkan ke siswa. Perangkat pembelajaran diarsipakan agar rapi dan disimpan dengan baik, selain untuk merencanakan kegiatan pembelajaran, perangkat pembelajaran tersebut digunakan untuk keperluan akreditasi dan data kelengkapan lembaga pendidikan.

\section{e. Sebagai Komunikator}

Guru menyampaikan materi pembelajaran dengan jelas dan menggunakan bahasa yang mudah dimengerti oleh siswa. Guru selalu memberikan informasi penting yang berkaitan dengan kegiatan di sekolah. Guru memberitahu siswa ketika akan 
melaksankaan PTS, guru menginformasikan siswa setiap ada kegiatan di kelas atau sekolah seperti pada kegiatan bulan suci ramadhan. Guru juga terlihat menginformasikan manfaat kegiatan pembelajaran yang dilakukan siswa di sekolah. Guru juga terlihat memberi informasi penting dalam pembelajaran seperti dalam pembuatan tugas dirumah guru menginformasikan kepada siswa cara mengerjakan tugas yang diberikan.

\section{f. Sebagai Motivator}

Cara guru memotivasi siswa agar aktif dalam pembelajaran yaitu memberi pujian atau hadiah kepada siswa yang berani tampil di depan kelas. Dan memacu dengan memberi semangat siswa yang belum berani tampil di depan kelas hingga akhirnya berani untuk tampil di depan kelas.

\section{g. Sebagai Inspirator}

Cara guru menginspirasi siswa yaitu: Pertama guru memberitahu kepada siswa manfaat belajar untuk masa depan. Kedua, guru memberikan kisah-kisah yang inspiratif dan mengaitkan dengan kehidupan sehari-hari. Kisah inspiratif dapat merangsang siswa untuk semangat dalam belajar, siswa akan terpacu untuk meniru apa yang dicontohkan oleh guru. Ketiga, guru memberikan dorongan berupa pengalaman hidup. Pengalaman hidup guru bisa berupa pengalaman dalam menjalani kehidupan sehari-hari, pengalaman menempuh pendidikan yang penuh dengan perjuangan, pengalaman hidup bersama orang-orang sekitar yang memberikan inpirasi bagi siswa.

\section{h. Sebagai Pendidik}

Peserta didik seringkali diberi tahu oleh guru bahwa ia tidak boleh melakukan hal-hal negatif, harus lebih mawas diri, serta harus lebih mengendalikan emosi. Sering kali selain menasihati siswa, guru mengingatkan siswa untuk berwudhu dan mengingatkan siswa untuk mengucapkan istighfar ketika melakukan kesalahan dan hal yang tidak baik.

\section{i. Sebagai Evaluator}

Guru selalu melakukan penilaian berupa tes yaitu melakukan ulangan harian dan penilaian semester. Penilaian non tes berupa penilaian sikap dan catatan sholat siswa. Dalam menilai dan mengembangkan sikap sosial tidak hanya dapat dilakukan oleh guru didalam pembelajaran tetapi dapat juga dilakukan diluar pembelajaran. Tidak hanya 
guru, seluruh civitas akademik yang menjadi bagian dari sekolah sangat berpengaruh untuk mengembangkan sikap sosial siswa di sekolah tersebut.

Seluruh guru, baik wali kelas maupun guru mapel atau seluruh civitas akademik MTs Nurul Fatah Tenggir termasuk satpam, ikut menggerakan semua kegiatan pengimplementasian dari sikap sosial. Contohnya kegiatan hidden curriculum. Kegiatan tersebut mengembangkan sikap santun siswa untuk menghargai orang yang berbicara di depan. Kemudian ketika berwudhu membudayakan antri.

Kemudian mengajarkan tanggung jawab dengan adanya kegiatan piket, apabila siswa tidak melaksanakan maka dikenakan sanksi. Jadi, sikap sosial yang terimplementasi dari setiap kegiatan di sekolah yaitu pada kegiatan hidden curriculum dan KBM.

\section{PEMBAHASAN}

\section{a. Sebagai Demonstrator}

Sebagai demonstrator, segala sesuatu yang dilakukan oleh guru akan menjadi panutan bagi siswa. Guru melakukan perannya sebagai demonstrator yakni, selalu berpakain sopan, memulai dan mengakhiri pembelajaran dengan tepat waktu, membimbing siswa untuk membaca do'a sebelum dan sesudah melakukan pekerjaan, menjawab salam, sehingga mengembangkan sikap disiplin dan sikap santun dalam diri siswa. Guru juga mengaitkan materi pelajaran dengan kehidupan nyata sehingga mengembangkan sikap siswa untuk menghargai orang yang sedang berbicara di depan kelas.

Hal ini sesuai dengan yang diungkapkan oleh Wina Sanjaya bahwa sebagai demonstrator, guru harus menunjukkan sikap-sikap yang terpuji dalam setiap aspek kehidupan. Guru harus dapat menunjukkan bagaimana caranya agar setiap materi pelajaran bisa lebih dipahami dan dihayati oleh setiap anak.

\section{b. Sebagai Pengelola Kelas}

Guru adalah sosok yang mengarahkan siswa untuk terus mau belajar hingga terjadi perubahan dalam diri siswa. Sebagai pengelola kelas, guru pelajaran sudah menjalankan perannya yakni, mengatur tempat duduk siswa setiap seminggu sekali menjadi 5 kelompok belajar, menentukan siswa yang memimpin berdo "ea berdasakan absen sehingga mengembangkan sikap percaya diri siswa dalam berbuat kebaikan.

\section{c. Sebagai Mediator}


Guru sudah menjalankan perannya sebagai mediator, yaitu menyediakan media pembelajaran berupa LCD dan proyektor, guru pelajaran melibatkan siswa untuk menggunakan media pembelajaran sehingga mengembangkan rasa percaya diri siswa untuk mencoba hal yang belum pernah dilakukan dan rasa tanggung jawab siswa untuk merapikan dan menjaga media tersebut dengan baik. Sebagaimana yang diungkapkan oleh Syaiful Bahri Djamarah bahwa guru sebagai mediator juga diartikan sebagai penyedia media pembelajaran.

\section{d. Sebagai Fasilitator}

Guru sebagai fasilitator memiliki kewajiban untuk memfasilitasi kegiatan belajar mengajar. Sebagaimana yang dilakukan guru pelajaran sudah menjalankan perannya sebagai fasilitator yakni, membuat Rencana Pelaksanaan Pembelajaran (RPP) semester genap, menyiapkan worksheet sebagai bahan evaluasi dan latihan siswa terhadap pemahaman pada pembelajaran tersebut. Sehingga guru mempunyai target untuk mencapai sikap sosial siswa yang akan dikembangkan seperti sikap disiplin dalam mengerjakan worksheet.

\section{e. Sebagai Komunikator}

Sebagai komunikator, guru sudah menjalankan perannya, yaitu menyampaikan materi pelajaran dengan jelas, menyampaikan manfaat kegiatan pembelajaran yang dilakukan siswa di sekolah dan memberi siswa informasi penting dalam setiap pembelajaran agar memunculkan rasa keingintahuan siswa, guru juga mendengarkan keluh kesah atas ketidaknyamanan siswa dalam belajar sehingga mengembangkan sikap percaya diri siswa untuk mengemukakan pendapat.

Sebagaimana pendapat Sholeh Hidayat bahwa seorang guru harus siap memberi informasi yang berupa aspek kognitif, afektif maupun keterampilan dan guru merupakan sumber siswa untuk bertanya.

\section{f. Sebagai Motivator}

Guru sudah menjalankan perannya sebagai motivator yakni, memberikan pujian atau apresiasi kepada siswa yang berani tampil di depan kelas, mendorong siswa yang belum berani tampil di depan kelas dengan memberinya kesempatan hingga rasa ketakutan siswa hilang. Peran tersebut mengembangkan sikap percaya diri. Guru juga memotivasi siswa untuk membantu teman yang kesulitan dalam belajar sehingga mengembangkan sikap peduli. 
Sesuai dengan hasil penelitian Shanghais Yan bahwa guru perlu memotivasi dengan membantu peserta didik untuk memperoleh pengetahuan dan keterampilan serta memotivasi peserta didik untuk belajar secara aktif dan mandiri.

\section{g. Sebagai Inspirator}

Guru adalah sosok yang menginspirasi bagi para siswa. Dalam menjalankan perannya sebagai inspirator, yaitu memberikan kisah-kisah yang inspiratif dan mengaitkan dengan kehidupan sehari-hari. Kisah inspiratif dapat merangsang siswa untuk semangat dalam belajar. Menceritakan pengalaman hidup guru dalam menjalani kehidupan sehari-hari, pengalaman menempuh pendidikan yang penuh dengan perjuangan, pengalaman hidup bersama orang-orang sekitar yang memberikan inpirasi bagi siswa. Sehingga sikap yang dapat berkembang dalam diri siswa yaitu percaya diri untuk terus menggapai cita-cita.

Sesuai dengan pendapat Saifuddin Azwar, apa yang telah dan sedang kita alami akan ikut membentuk dan mempengaruhi penghayatan kita terhadap stimulus sosial.

\section{h. Sebagai Pendidik}

Guru adalah sosok yang memiliki kewajiban untuk mendidik siswa dengan ilmu yang telah dimilikinya agar siswa memiliki pribadi yang baik. Guru sudah menjalankan perannya sebagai pendidik yaitu, memakai pakaian selalu rapi, perkataan dan ucapan guru selalu baik, menghargai para siswanya. Sehingga mengembangkan sikap santun siswa.

\section{i. Sebagai Evaluator}

Guru sebagai evaluator mampu melakukan penilaian terhadap siswa baik penilaian tes, maupun non tes. Menjalankan perannya sebagai evaluator yaitu, guru memberikan penilaian harian berupa penilaian sikap anak dan mengawasi siswa ketika melaksanakan Penilaian Tengah Semester (PTS). Guru juga melakukan penilaian terhadap sikap sosial siswa ketika pembelajaran berlangsung. Hal ini dapat mengembangkan sikap jujur siswa dalam bertindak. Hal ini sebagaimana yang diungkapkan oleh Rusman, dalam dunia pendidikan selalu diadakan evaluasi artinya penilaian yang telah dicapai, baik oleh pihak terdidik maupun pendidik. 


\section{KESIMPULAN}

1. Sikap sosial yang dikembangkan di MTs Nurul Fatah Tenggir pada pembelajaran IPS yaitu: jujur, disiplin, percaya diri, tanggung jawab, santun, dan peduli.

2. Peran guru dalam mengembangkan sikap sosial pada pembelajaran IPS yaitu:

a. Guru sebagai demonstrator, guru memulai dan mengakhiri pembelajaran tepat waktu, menunjukkan cara berpakaian rapi, sopan dan islami, berbicara dengan baik, menjawab salam, membimbing siswa untuk berdo ${ }^{e c}$, serta menunjukkan cara agar setiap materi yang diajarkan dapat dipahami siswa. Peran tersebut mengembangkan sikap sosial siswa terutama disiplin dan santun.

b. Guru sebagai pengelola kelas, guru mengatur tempat duduk siswa, mengatur jadwal siswa dalam memimpin do ${ }^{e c}$. Peran tersebut mengembangkan sikap percaya diri. Sebagai pengelola kelas guru juga melibatkan siswa dalam kegiatan kebersihan atau piket kelas sehingga mengembangkan sikap tanggung jawab.

c. Guru sebagai mediator, guru menyediakan dan melibatkan siswa dalam menggunakan media pembelajaran. Peran tersebut mengembangkan sikap tanggung jawab siswa.

d. Guru sebagai fasilitator, guru memfasilitasi kebutuhan siswa dan tidak bertindak sewenang-wenang. Peran tersebut mengembangkan sikap jujur.

e. Guru sebagai komunikator, guru memberikan informasi yang memunculkan rasa keingintahuan siswa sehingga mengembangkan sikap percaya diri terutama dalam mengemukakan pendapat.

f. Guru sebagai motivator, guru memberi pujian dan mendorong siswa untuk berani tampil di depan kelas sehingga mengembangkan sikap percaya diri.

g. Guru juga memotivasi siswa untuk membantu teman yang kesulitan sehingga mengembangkan sikap peduli siswa.

h. Guru sebagai inspirator, guru memberikan kisah inspiratif sehingga mengembangkan sikap percaya diri siswa.

i. Guru sebagai pendidik, guru menasihati siswa sehingga mengembangkan sikap tanggung jawab siswa.

j. Guru sebagai evaluator, guru melakukan penilaian tes dan non tes sehingga mengembangkan sikap jujur siswa.

\section{DAFTAR PUSTAKA}


Abd Kadir dan Hanun Asrohah, 2015. Pembelajaran Tematik. Jakarta: PT Raja Grafindo Persada

Ade Sanjaya, Pengertian Peranan Definisi Menurut Para Ahli. (http://www.landasanteori.com/2015/10/pengertian-peranan-definisimenurut.html), diunduh pada hari Selasa, 20 Januari 2021 pukul 15.40 WIB.

Ashliy Dien Bakir, Peran Guru dalam Pengelolaan Kelas. (https://id.scribd.com/doc/93466360/Peran-Guru-Dalam-Pengelolaan-Kelas), diunduh pada hari Sabtu, 23 Januari 2020 pukul 09.26 WIB.

Azam Farah Bidjari, "Attitude and Social Representation". Procedia Social and BehavioralScience(https://www.sciencedirect.com/science/../S18770428110213..) , diunduh pada hari Kamis, 25 Januari 2021 pukul 00.36 WIB.

Desmita. 2010. Psikologi Perkembangan Peserta Didik. Bandung: PT Remaja Rosdakarya.

Fika Aprilia, "Strategi Guru dalam Membentuk Sikap Sosial Siswa Kelas I di MIN Malang I", Skripsi, Universitas Islam Negeri Maulana Malik Ibrahim, 2015, (etheses.uin-malang.ac.id/5374/1/11140009.pdf), diunduh pada hari Rabu, 20 Januari 2021 pukul 23.50 WIB.

Heri Gunawan, Pendidikan Karakter. 2012. Konsep dan Implementasi. Bandung: Penerbit Alfabeta.

Habel, "Peran Guru Kelas Membangun Perilaku Sosial Siswa Kelas V Sekolah Dasar 005 Di Desa Setarap Kecamatan Malinau Selatan Hilir Kabupten Malinau", eJournal Sosiatri-Sosiologi, 2015, (ejournal.sos.fisipunmul.ac.id/.../JURNAL\%20HABEL\%20(02-26-15-05-36-44).pdf), diunduh pada hari Rabu, 20 Januari 2020 pukul 23.49 WIB.

Jenny Mercer \& Debbie Clayton, 2012. Psikologi Sosial. Jakarta: Penerbit Erlangga.

Jumanta Hamdayana, 2016. Metodologi pengajaran. Jakarta: Bumi Aksara.

Kamus Besar Bahasa Indonesia Online (KBBI), (https://www.kbbi.web.id/peran), diunduh pada hari Selasa, 20 Januari 2021 pukul 15.49 WIB. Indonesiastudent, (http://www.indonesiastudents.com/pengertian-peran-menurut-paraahli-danjenisnya/), diunduh pada hari Rabu, 21 Januari 2021 pukul 15.36 WIB.

Kementrian Pendidikan dan kebudayaan, 2015. Panduan Penilaian untuk Sekolah Menegah Pertama (SMP).

Momon Sudarma, 2013. Profesi Guru: Dipuji, Dicaci, Dan Dikritis, (Jakarta: PT Raja Grafindo Persada.

Muchlas Samani dan Hariyanto, 2011. Konsep dan Model Pendidikan Karakter. Bandung: PT Remaja Rosdakarya. 
Muhammad Takdir Ilahi, 2016. Revitalisasi Pendidikan Berbasis Moral. Jogjakarta: ArRuzz Media.

Muhibbin Syah, 2010. Psikologi Pendidikan dengan Pendekatan Baru. Bandung: PT Remaja Rosdakarya.

Mally Mealiah, "Peran Guru dalam Menyiapkan Kompetensi Kerja Siswa Sesuai Tuntutan Dunia Kerja di Industri Busana", Seminar Internasional, (https://media.neliti.com/media/publications/224713-peran-guru-dalammenyiapkan-kompetensik-55692556.pdf), diunduh pada hari Rabu , 20 Januari 2021 pukul 07.37 WIB.

Ngalim Purwanto, 2014. Ilmu Pendidikan Teoritis dan Praktis. Bandung: PT Remaja Rosdakarya.

Najib Sulhan, 2011. Karakter Guru Masa Depan Sukses \& Bermartbat. Surabaya: Jaring pena.

Nasehudin, "Pembentukan Sikap Sosial Melalui Komunikasi dalam Keluarga", Jurnal Edueksos, Vol. IV, No. 1, Juni 2015, Jurusan Tadris IPS IAIN Syekh NurjatiCirebon,(syekhnurjati.ac.id/jurnal/index.php/edueksos/article/view/647 diunduh pada hari Senin, 24 Januari 2020 pukul 07.36 WIB.

Nafia Wafiqni dan Asep Ediana Latip, 2015. Psikologi Perkembangan Anak Usia MTs, SMP, Jakarta: UIN Press.

Nuraida dan Rihlah Nur Aulia, 2010. Pendidikan Karakter untuk Guru. Jakarta: Aulia Publishing House.

Peraturan Menteri Pendidikan Dan Kebudayaan Republik Indonesia Nomor 23 Tahun 2016 Tentang Standar Penilaian Pendidikan, (http://bsnpIndonesia.org/wpcontent/uploads/2009/09/Permendikbud_Tahun2016_Nomor023 .pdf), diunduh pada hari Jum'at, 26 Januari 2021 pukul 07.43 WIB

Pupuh Fathurrohman dan Aa Suryana, 2012. Guru Profesional. Bandung: PT Refika Aditama.

Rusman, 2014. Model-Model Pembelajaran. Jakarta: Rajawali Pers.

Ria Agustina, 2017. Peran Guru sebagai Fasilitator dalam Proses Pembelajaran Pendidikan Agama Islam di SMP Negeri I Wonosobo Kabupaten Tenggmus, skripsi, Fakultas Tarbiyah dan Keguruan UIN Raden Intan Lampung. diunduh pada hari Sabtu 23 Januari 2020 pukul 13.57 WIB.

Saifuddin Azwar, 2015. Sikap Manusia: Teori dan Pengukurannya. Yogyakarta: Pustaka Pelajar. 
Sholeh Hidayat, 2017. Pengembangan Guru Profesional. Bandung: PT Remaja Rosdakarya.

Shanghais Yan, 2012. "Teacher"s Roles In Autonomous Learning", Journal of Sociological Researc. (http://dx.doi.org/10.5296/jsr.v3i2.2860), diunduh pada hari Senin, 24 Januari 2021 pukul 08.25 WIB.

Syamsu Yusuf dan Nani M. Sugandhi, 2011. Perkembangan Peserta Didik. Jakarta: PT Raja Grafindo Persada, 2011.

Syaiful Bahri Djamarah, 2010. Guru dan Anak Didik dalam Interaksi Edukatif. Jakarta: Rineka Cipta.

Sutarjo Adisusilo, 2012. Nilai Karakter: Konstruktivisme dan VCT sebagai Inovasi Pendekatan Pembelajaran Afekti., Jakarta: Rajawali Pers.

Sunarto dan Agung Hartono. 2008. Perkembangan Peserta Didik. Jakarta: Rineka Cipta.

Wahyu Widodo, dkk., 2016. Implementasi Pembelajaran Tematik di Sekolah Dasar. Bandung: PT Remaja Rosdakarya.

Yanti Herlianti, 2015. Pembelajaran Tematik, Jakarta: UIN Press 